\title{
American Woodcock Status
}

MARK SEAMANS, ${ }^{1}$ U.S. Fish and Wildlife Service, Division of Migratory Bird Management, 755 Parfet Street, Suite 235, Lakewood, CO 80215.

REBECCA RAU, U.S. Fish and Wildlife Service, Division of Migratory Bird Management, Patuxent Wildlife Research Center, 11510 American Holly Drive, Laurel, MD 20708

\begin{abstract}
Annual assessment of American woodcock (Scolopax minor; hereafter, woodcock) populations in North America relies primarily on the American Woodcock Singing-Ground Survey (SGS). Ancillary information concerning harvest and hunting effort comes from the Harvest Information Program (HIP), and indices of recruitment come from Wing Collection Surveys (WCS). We report on long-term trends in SGS, HIP, and WCS data in the Eastern and Central Management Regions in the U.S. Analyses of SGS data indicate there have been significant long-term (1968-2017) declines of 1.05\% per year in the Eastern Management Region and - $0.56 \%$ per year in the Central Management Region. Discontinuance of some routes and their replacement with new routes may have artificially lessened the long-term negative trends in the SGS. Since 2013, total harvest and number of days hunters spent pursuing woodcock have been below the long-term average (1999-2015) in both management regions. Age ratios (number of immatures per adult female) were temporally variable but exhibited no long-term trend in the Eastern Management Region. In the Central Management Region, age ratios were generally higher during the beginning of the study (1963-1987) period versus the latter part (1988-2016).
\end{abstract}

Proceedings of the American Woodcock Symposium 11: 9-17

KEY WORDS: American woodcock, harvest, population status, Scolopax minor, Singing Ground Survey

The American woodcock (Scolopax minor; hereafter, woodcock) is a popular game bird throughout eastern North America. The management objective of the U.S. Fish and Wildlife Service (FWS) is to increase populations of woodcock to levels consistent with the demands of consumptive and non-consumptive users (U.S. Fish and Wildlife Service 1990). Reliable annual population estimates, harvest estimates, and information on recruitment and spatial distribution are essential for comprehensive woodcock management; however, this information is difficult and often impractical to obtain. Woodcock are difficult to find and count because of their cryptic coloration, small size, and preference for areas with dense vegetation. The Singing-Ground Survey (SGS) was developed to coincide with the conspicuous courtship display of the male woodcock. Early studies demonstrated that counts of singing males provided reliable indices of woodcock populations and could be used to monitor annual changes (Mendall and Aldous 1943, Goudy 1960, Duke 1966, Whitcomb 1974).
The SGS only supplies an index to population change and does not directly address harvest or the effect of harvest on woodcock populations (Sauer and Bortner 1991). The Wing Collection Survey (WCS) provides annual indices of woodcock recruitment. Wings are collected from hunters each year, the age of each submitted wing is determined at an annual woodcock wingbee, and the resultant age ratios provide the recruitment index. Hunters who hunt woodcock (or any migratory game bird) are required to register for the Harvest Information Program (HIP) and answer a set of questions regarding what species they hunt. From this information the FWS determines which hunters are surveyed to estimate the annual number of woodcock harvested and hunting activity. The HIP was cooperatively developed by the FWS and state wildlife agencies in 1999 to provide reliable annual estimates of hunter activity and harvest for all migratory game birds (Elden et al. 2002). Prior to 1999, the annual FWS migratory bird harvest survey (Mail Questionnaire Survey)

1 email: mark_seamans@fws.gov 
for all migratory game birds was based solely on hunters who purchased a federal duck stamp. The American Woodcock Harvest Strategy (Woodcock Harvest Strategy Working Group 2010) relies solely on trends derived from the SGS to inform annual harvest management decisions. Although WCS and HIP information are examined, they currently have no role in regulatory decisions.

Here we examine trends in SGS at varying temporal scales to estimate population status, and report estimates of age ratio and harvest statistics from WCS and HIP. However, the SGS data, and their use as a population assessment tool, are subject to a number of potential problems. Chief among these is the ability of the SGS index to accurately depict changes in true abundance (Dwyer et al. 1988, Sauer and Bortner 1991, Case 2010). Both Straw et al. (1994) and Case (2010) recommended addressing assumptions related to the SGS, and improvement of analytical techniques and survey methods. The spatial coverage of the survey may not extend far enough north or south in the breeding range (Moore et al. 2019), and the lack of a survey method that accounts for detection probability has the potential to cause misleading inferences. We address 1 issue regarding representativeness, that of discontinuing some SGS routes and replacing them with new routes, which may be in areas of higher quality for woodcock, thus biasing annual indices. We compare counts of woodcock at discontinued routes with counts from their replacement routes to estimate this potential bias.

\section{Study Area}

Our study area encompassed the majority of woodcock distribution in North America (Fig. 1). The woodcock breeding range extends from southern Canada through the eastern U.S. east of $98^{\circ} \mathrm{W}$ (McAuley et al. 2013), whereas woodcock generally winter south from Maryland and southern New Jersey in the eastern U.S, and west into central Texas and Oklahoma. Two Management Regions were recognized by the FWS, the Eastern and the Central, and the boundary coincided with the boundary between the Atlantic and Mississippi Flyways (Fig. 1). HIP data were collected from hunters from all states within the range of the woodcock (Seamans and Rau 2017). Wings were also collected from hunters in all states within the range of the woodcock for the WCS, but most came from northern states (Seamans and Rau 2017). The SGS provided information from most of the breeding range but did not cover the very northern portion of the range in Ontario and Quebec, nor the very southern part of the range in the eastern U.S. (Seamans and Rau 2017).

\section{Methods}

\section{AMERICAN WOODCOCK SINGING-} GROUND SURVEY (SGS)

Before 1968, counts of woodcock were conducted on non-randomly-located routes. Beginning in 1968, routes were relocated along lightly-traveled secondary roads in the center of randomly-chosen 10-minute degree blocks within each state and province in the central and northern portions of the woodcock's breeding range (Fig. 1). Therefore, data collected prior to 1968 were not included in this analysis. Routes were surveyed by an observer who drove to each of 10 stops and recorded the number of woodcock heard peenting (the vocalization by the displaying male woodcock on the ground). Acceptable dates for conducting the survey were assigned by latitude to coincide with peaks in courtship behavior of local woodcock. In most states and provinces, the peak of courtship activity (including local woodcock and woodcock still migrating) occurred earlier in the spring than the start of the survey and local reproduction may have already been underway when the survey was conducted. However, it was necessary to conduct the survey during the designated survey dates to minimize counting migrating woodcock twice, i.e., once during migration and once on their breeding grounds. Because adverse weather conditions may have affected courtship behavior and/or the ability of observers to hear woodcock, surveys were not conducted in strong wind, heavy precipitation, or when temperature was $<5^{\circ} \mathrm{C}$.

The SGS consists of approximately 1,500 routes. Approximately two-thirds of these routes are surveyed each year, whereas approximately one-third are counted as "constant zero" routes for which no woodcock are heard for 2 consecutive years. To avoid expending unnecessary resources and funds, routes with constant zero status are not run for the next 5 years. If woodcock are heard on a constant zero route during its next survey, the route reverts to normal status and is surveyed again each year.

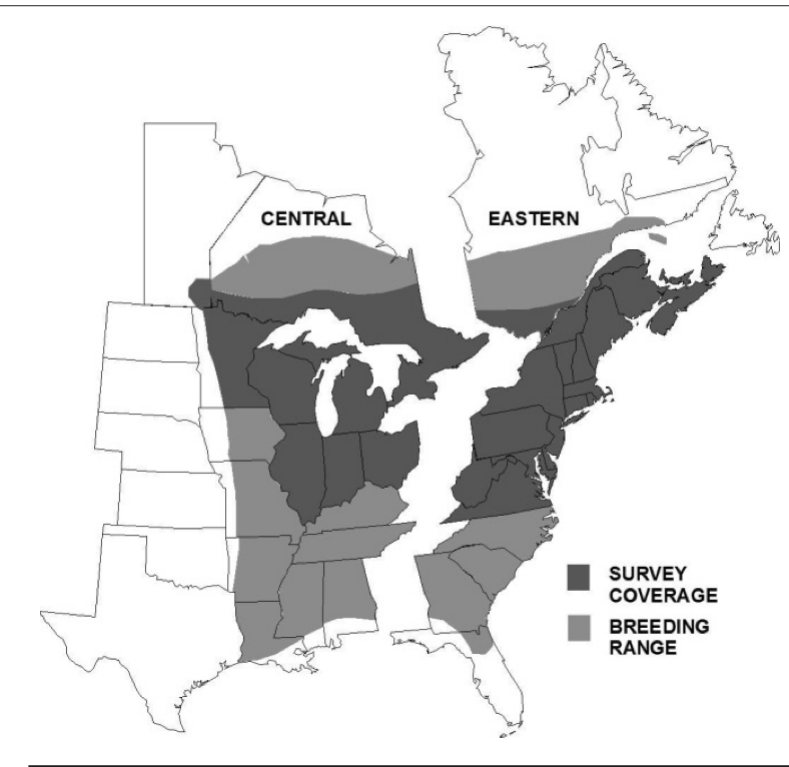

Figure 1. American woodcock management regions, breeding range, and Singing-Ground Survey coverage in eastern North America. 
Data from constant zero routes are included in the analysis only for the years they were surveyed. Sauer and Bortner (1991) reviewed the implementation and analysis of the SGS in more detail and found estimates of population trend with and without constant zero routes were similar.

Each SGS route was targeted for survey between 22 and 58 minutes after sunset on clear evenings or between 15 and 51 minutes after sunset on overcast evenings. Due to observer error, some stops on some routes were surveyed before or after the peak times of singing activity. Earlier analysis revealed that counts from routes with $\leq 8$ acceptable stops tended to be biased low; therefore, we included only route observations with $\geq 9$ acceptable stops in our analysis. Our analysis was restricted to data received prior to 30 June 2017. We report sample sizes as the number of routes on which trend estimates are based, which includes any route on which woodcock were ever encountered.

We estimated temporal trends using a hierarchical model applied to SGS data collected from 1968 to 2017. Sauer et al. (2008) describe a hierarchical log-linear model for estimation of population change from SGS data. With the hierarchical model, the log of the expected value of the counts is modeled as a linear combination of strata-specific intercepts and year effects, a random effect for each unique combination of route and observer, a start-up effect on the route for first year counts by new observers, and over dispersion. The parameters of interest are treated as random and are assumed to follow distributions that are governed by additional parameters. The hierarchical model is fit using Bayesian methods. Markov-chain Monte Carlo methods are used to iteratively produce sequences of parameter estimates that can be used to describe the distribution of the parameters of interest. After an initial "burn-in" period, means, medians, and credible (or Bayesian confidence) intervals (CI) for the parameters can be estimated from the replicates. Annual indices are defined as exponentiated strata underlying trend, and year effects, which are then weighted by the proportion of routes where $\geq 1$ woodcock was observed between 1968 and 2017. Trends are defined as ratios of the indices at the start and end of the interval of interest, taken to the appropriate power to estimate a yearly change (Sauer et al. 2008). Trend estimates are expressed as percent change per year, whereas indices are expressed as the number of singing males per route. We calculated annual indices for the 2 regions and for each state and province, and short-term (2016-2017), 10-year (2007-2017) and long-term (1968-2017) trends for each region and for each state or province.

Credible Intervals are used to describe uncertainty around estimates when fitting hierarchical models. If the CI does not overlap o for a trend estimate, the trend is considered significant. We present the median and 95\% CIs of 10,000 estimates (i.e., we simulated 20,000 replicates and thinned by 2 ), which were calculated after an initial
20,000 iterations to allow the series to converge. Refer to Sauer et al. (2008) and Link and Sauer (2002) for a detailed description of the statistical model and fitting process.

SGS routes can be discontinued and replaced with new routes if: (1) running the route becomes a safety hazard, (2) an increase in noise level permanently alters the accuracy of woodcock counts at $\geq 2$ stops along a route, or (3) a permanent change in road condition precludes further survey. Replacement routes are located within the 10-minute block of the original route and it is recommended that the replacement route be within $\sim 4.8 \mathrm{~km}$ ( 3 miles) of the original start location. We estimated the effect of route replacement on SGS counts by comparing the average of counts during the last 3 years at a discontinued route with the average of counts during the first 3 years at its replacement route. For an individual matched pair (discontinued-replacement), we didn't conduct comparisons if no surveys were done during the last 3 years at the discontinued route or the first 3 years at the replacement route.

\section{WING COLLECTION SURVEY (WCS)}

The primary objective of the WCS is to provide data on the annual reproductive success of woodcock. The survey is administered as a cooperative effort among woodcock hunters, the FWS, and state wildlife agencies. Participants in the survey include hunters who: (1) participated in past surveys, (2) were a subset of hunters that indicated on the HIP Survey that they hunted woodcock, or (3) contacted the FWS to volunteer for the survey. WCS participants were provided with prepaid mailing envelopes and were asked to submit 1 wing from each woodcock they harvested. Hunters were asked to record the date of the hunt and the state and county where the woodcock was shot. Hunters were not asked to submit envelopes for unsuccessful hunts. The age and sex of woodcock were determined by examining plumage characteristics (Martin 1964, Sepik 1994) during an annual woodcock wingbee conducted by state, federal, and private biologists.

We used the ratio of immature birds per adult female in the harvest as an index to recruitment of young into the population. We calculated the annual recruitment index for each state with $\geq 125$ submitted wings as the number of immatures per adult female. We weighted regional indices by the relative contribution of each state to the cumulative number of adult female and immature wings received during 1963-2015. We calculated percent change for all comparisons using unrounded recruitment indices.

\section{HARVEST INFORMATION PROGRAM (HIP)}

The HIP sampling frame consists of all migratory gamebird hunters. Under this program, state wildlife agencies collect the name, address, and additional information from each migratory bird hunter in their state and send that information to the FWS. The FWS then selects ran- 
dom samples of those hunters and asks them to voluntarily provide detailed information about their hunting activity. For example, hunters selected for the woodcock harvest survey were asked to complete a daily diary about their woodcock hunting and harvest activities during the current year's hunting season. Their responses were then used to develop nationwide woodcock harvest estimates. HIP survey estimates of woodcock harvest have been available since 1999. Although estimates from 1999-2002 have been finalized, the estimates from 2003-2016 should be considered preliminary as refinements are still being made in the sampling frame and estimation techniques (Raftovich et al. 2017). We obtained Canadian hunter and harvest estimates through the Canadian National Harvest Survey Program (Gendron and Smith 2016). HIP data are not used to inform annual regulatory decisions. We examined annual HIP estimates of harvest and hunter days afield for general changes over time or between Management Regions. The annual number of hunters or hunter success cannot be obtained due to the occurrence of individual hunters being registered in the HIP in $\geq 1$ state.

\section{Results}

\section{SINGING GROUND SURVEY}

A total of 1,513 SGS routes had $\geq 1$ woodcock detected $\geq 1$ year during 1968-2017 (Table 1). We estimated 10-year (2007-2017) and long-term (1968-2017) trends using data from 787 routes in the Eastern Management Region and 744 routes in the Central Management Region. Short-term analysis indicated that the number of woodcock heard singing during the 2017 SGS declined from 2016 for the Eastern Management Region and remained stationary for the Central Management Region (Table 1). Trends for individual states and provinces are reported in Table 1.

The 10-year trend (2007-2017) showed a significant decline for the Eastern Management Region, whereas there was no significant trend for the Central Management Region (Table 1). Many states and/or provinces in both management regions have experienced significant longterm (1968-2017) declines (Table 1). The long-term trend estimates (1968-2017; Fig. 2) indicated significant population declines in both the Eastern $(-1.05 \% /$ year, $95 \% \mathrm{CI}=$ -0.76 to 1.32$)$ and Central (-0.56\%/year, $95 \% \mathrm{CI}=-0.33$ to - 0.79 ) Management Regions. In the Eastern Management Region, the 2017 index was 2.41 singing males per route, whereas it was 2.92 in the Central Management Region.

Since 1968, 170 and 155 routes have been discontinued in the Eastern and Central Management Regions, respectively. The rate at which routes were discontinued and replaced was distributed relatively even among years from 1968-2017 (range 0-9 per year in the Eastern Management Region, $0-8$ in the Central Management Region). Using a 3-year average of males per route in the Eastern Region, $55 \%$ of replacement routes had an index greater than the routes they replaced, $15 \%$ had a lower index than routes they replaced, and 30\% matched the routes they replaced with a mean index value of zero (Fig. 3). In the Central Management Region, $47 \%$ of replacement routes had an index greater than the routes they replaced, $19 \%$ had an index lower than routes they replaced, and 34\% matched the routes they replaced with a mean index value of zero (Fig. 3).

\section{WING COLLECTION SURVEY}

More than 700,000 wings have been received from hunters since 1963 (Table 2). On average, recruitment indices in each Management Region appeared to be higher from 1963-1988 than after 1988 (Fig. 4). The 2016 recruitment index in the U.S. portion of the Eastern Management Region (1.42 immatures per adult female) was $12.3 \%$ less than the long-term (1963-2015) regional average, whereas in the Central Management Region, the 2016 recruitment index (1.32 immatures per adult female) was $14.3 \%$ less than the long-term regional average.

\section{HARVEST INFORMATION PROGRAM}

In the Eastern Management Region, woodcock hunters spent an estimated 96,100 days afield and harvested 44,400 birds during the 2016-2017 hunting season. Har-

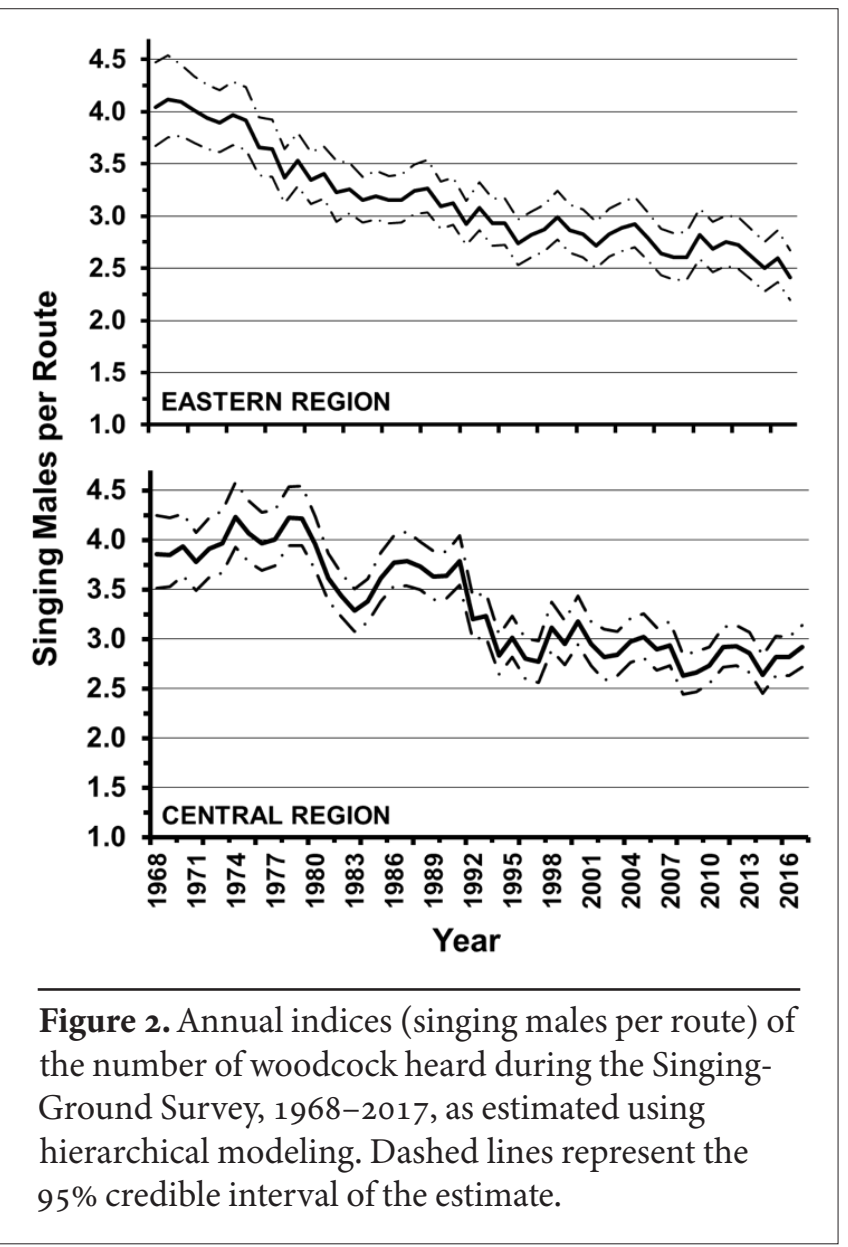


Table 1. Short-term (2016-17), 10-year (2007-2017), and long-term (1968-2017) trends (\% change per yeara) in the number of American woodcock heard per route during the Singing-Ground Survey as determined by using a hierarchical log-linear modeling technique (Sauer et al. 2008).

\begin{tabular}{|c|c|c|c|c|c|c|c|c|c|c|c|}
\hline \multirow{3}{*}{$\begin{array}{l}\text { State, } \\
\text { province, } \\
\text { or region }\end{array}$} & \multirow{3}{*}{$\begin{array}{r}\text { No. } \\
\text { routes }^{\mathrm{a}}\end{array}$} & \multirow[b]{3}{*}{$n^{b}$} & \multicolumn{3}{|c|}{$2016-2017$} & \multicolumn{3}{|c|}{$2007-2017$} & \multicolumn{3}{|c|}{$1968-2017$} \\
\hline & & & & \multicolumn{2}{|c|}{$95 \% \mathrm{CI}^{\mathrm{d}}$} & \multicolumn{3}{|c|}{$95 \% \mathrm{CI}^{\mathrm{d}}$} & \multirow[b]{2}{*}{$\%$ change $^{c}$} & \multicolumn{2}{|c|}{$95 \% \mathrm{CI}^{\mathrm{d}}$} \\
\hline & & & $\%$ change $^{c}$ & lower & upper & $\%$ change $^{c}$ & lower & upper & & lower & upper \\
\hline $\mathrm{CT}$ & 3 & 11 & -2.47 & -38.61 & 55.51 & -1.68 & -5.57 & 4.51 & -2.49 & -4.29 & -0.61 \\
\hline $\mathrm{DE}$ & 1 & 3 & -5.97 & -89.40 & 567.29 & -3.20 & -20.47 & 19.73 & -3.65 & -9.09 & 1.42 \\
\hline $\mathrm{ME}$ & 50 & 73 & -16.03 & -31.09 & 1.05 & -1.58 & -3.54 & 0.35 & -1.36 & -1.86 & -0.86 \\
\hline MD & 7 & 26 & -2.78 & -24.68 & 33.85 & -3.73 & -6.37 & -0.45 & -3.78 & -5.15 & -2.31 \\
\hline MA & 9 & 22 & -5.01 & -29.84 & 18.54 & -2.45 & -5.06 & 0.35 & -2.52 & -3.50 & -1.53 \\
\hline NB & 55 & 72 & -21.97 & -36.54 & -3.80 & -2.83 & -4.95 & -0.71 & -1.35 & -2.13 & -0.58 \\
\hline $\mathrm{NH}$ & 12 & 18 & -10.34 & -36.71 & 17.90 & -0.35 & -3.37 & 2.86 & -0.77 & -1.79 & 0.21 \\
\hline NJ & 9 & 19 & -7.24 & -48.84 & 64.38 & -6.48 & -12.05 & -0.91 & -6.02 & -7.52 & -4.52 \\
\hline NY & 81 & 115 & 3.34 & -11.30 & 20.76 & 0.89 & -0.78 & 2.80 & -0.55 & -0.98 & -0.10 \\
\hline NS & 43 & 63 & -5.09 & -23.03 & 14.95 & -0.39 & -2.51 & 1.86 & -0.90 & -1.62 & -0.25 \\
\hline PA & 27 & 82 & -2.08 & -23.42 & 24.78 & -0.58 & -2.91 & 2.29 & -1.03 & -1.74 & -0.32 \\
\hline PEI & 9 & 13 & 12.33 & -14.27 & 76.51 & -1.05 & -4.44 & 2.57 & -1.08 & -2.24 & 0.20 \\
\hline QUE & 10 & 111 & -0.92 & -16.07 & 16.41 & -0.48 & -2.10 & 1.34 & -0.59 & -1.34 & 0.15 \\
\hline $\mathrm{RI}^{\mathrm{e}}$ & 0 & 3 & ----- & ----- & ----- & -12.02 & -21.77 & -1.11 & -11.78 & -17.70 & -6.01 \\
\hline VT & 16 & 24 & -10.93 & -37.34 & 21.03 & -1.04 & -4.41 & 2.54 & -0.83 & -1.76 & 0.15 \\
\hline VA & 20 & 75 & 0.65 & $-34 \cdot 37$ & 66.74 & -5.53 & -9.90 & -1.16 & -5.51 & -6.58 & -4.45 \\
\hline WV & 25 & 57 & -0.15 & -18.71 & 29.87 & -2.01 & -4.13 & 0.71 & -2.18 & -2.98 & -1.36 \\
\hline Eastern & 377 & 787 & -7.09 & -13.80 & -0.11 & -0.89 & -1.67 & -0.08 & -1.05 & -1.32 & -0.76 \\
\hline IL & 14 & 47 & 21.11 & -58.21 & 247.13 & -1.63 & -12.38 & 10.33 & -0.89 & -3.51 & 2.07 \\
\hline IN & 11 & 62 & -3.57 & -43.05 & 62.19 & -3.05 & -7.82 & 2.76 & -4.06 & $-5 \cdot 30$ & -2.88 \\
\hline $\mathrm{MB}^{\mathrm{f}}$ & 17 & 30 & 22.85 & -7.70 & 71.45 & 2.56 & -0.95 & 6.87 & 0.48 & -1.13 & 2.21 \\
\hline MI & 119 & 155 & 1.30 & -10.50 & 14.37 & 0.30 & -1.02 & 1.72 & -0.70 & -1.06 & -0.34 \\
\hline MN & 74 & 122 & 1.76 & -12.40 & 19.30 & 2.56 & 0.82 & 4.35 & 0.94 & 0.37 & 1.56 \\
\hline $\mathrm{OH}$ & 33 & 73 & -9.84 & -32.61 & 13.74 & -0.54 & -2.96 & 2.75 & -1.65 & -2.42 & -0.93 \\
\hline $\mathrm{ON}$ & 92 & 163 & 1.60 & -11.85 & 17.90 & -2.12 & -3.88 & -0.42 & -0.85 & -1.29 & -0.39 \\
\hline WI & 77 & 122 & 15.70 & -1.60 & 36.56 & 0.37 & -1.47 & 2.26 & -0.01 & -0.49 & 0.50 \\
\hline Central & 437 & 744 & 3.64 & -3.50 & 11.37 & -0.05 & -0.88 & 0.79 & -0.56 & -0.79 & -0.33 \\
\hline Continent & 814 & 1,531 & -1.53 & -6.46 & 3.64 & -0.44 & -1.01 & 0.14 & -0.80 & -0.98 & -0.61 \\
\hline $\begin{array}{ll}\text { a } & \text { Total numbe } \\
\text { b } & \text { Number of r } \\
\text { c } & \text { Median of ro } \\
\text { (10o( (\% cha } \\
\text { over time (e. } \\
\text { d } 95 \% \text { credible } \\
\text { e Insufficient } \\
\text { f Manitoba be }\end{array}$ & $\begin{array}{l}\text { rof routes s } \\
\text { outes with } \geq \\
\text { ute trends } \\
\text { ge/ } / 100)+1 \text { ) } \\
\text { g., } 30 \text { years) } \\
\text { interval; if } \\
\text { lata to calcu } \\
\text { gan particip }\end{array}$ & $\begin{array}{l}\text { urveyed in } \\
\text { year of } n \\
\text { stimated u } \\
\text { )-10o, wh } \\
\text { may exage } \\
\text { he interva } \\
\text { ate trend. } \\
\text { ating in th }\end{array}$ & $\begin{array}{l}2017 \text {, for whic } \\
\text { on-zero data b } \\
\text { ssed hierarchic } \\
\text { ere y is the nur } \\
\text { gerate the total } \\
\text { l overlaps zero } \\
\text { he Singing-Gro }\end{array}$ & $\begin{array}{l}\text { a data were } \\
\text { etween } 1968 \\
1 \text { modeling } \\
\text { ber of year } \\
\text { change ove } \\
\text { the trend i }\end{array}$ & $\begin{array}{l}\text { received by } 3 \\
\text { and } 2017 . \\
\text { To estimate } \\
\text { Note: extra } \\
\text { the period. } \\
\text { considered } \\
\text { in } 1992 .\end{array}$ & $\begin{array}{l}\text { o June } 2017 \text {. } \\
\text { the total percent } \\
\text { polating the esti } \\
\text { hon-significant. }\end{array}$ & $\begin{array}{l}\text { t change } o \\
\text { imated tre }\end{array}$ & $\begin{array}{l} \\
\text { ver several } \\
\text { nd statistic }\end{array}$ & $\begin{array}{l}\text { ears, use: } \\
\text { \% change per ye }\end{array}$ & & \\
\hline
\end{tabular}

vest in 2016-2017 was $45.9 \%$ less than the long-term (19992015) average ( 82,047 birds/year) and $18.5 \%$ less than the 2015-2016 season (54,500 birds; Fig. 5). Woodcock hunters in the Central Management Region spent an estimated 300,200 days afield and harvested 158 ,000 birds during the 2016-2017 hunting season. Harvest in 2016-2017 was 26.0\% less than the long-term (1999-2015; Fig. 5) average
$(213,400$ birds/year) and $8.4 \%$ more than the 2015-2016 season (145,700 birds).

Data from Canada show a long-term decline in both the number of successful woodcock hunters and harvest (Fig. 7; Roy et al., this volume). The most recent data available indicate that an estimated 3,862 successful hunters harvested 25,173 woodcock during the 2016 season in Can- 
ada (Gendron and Smith 2017). From 2006-2016, the average annual harvest in the U.S. and Canada combined was approximately 287,000 .

\section{Discussion}

One of the main objectives of the American Woodcock Conservation Plan (Kelley et al. 2008) was to halt population declines by 2012 as measured by the SGS. To meet this objective, the Conservation Plan recommended managing for early succession forest cover in clustered large patches (10os of ha). Halting the population decline has yet to occur in either management region, but it appears closest to being achieved in the Central Management Region. The

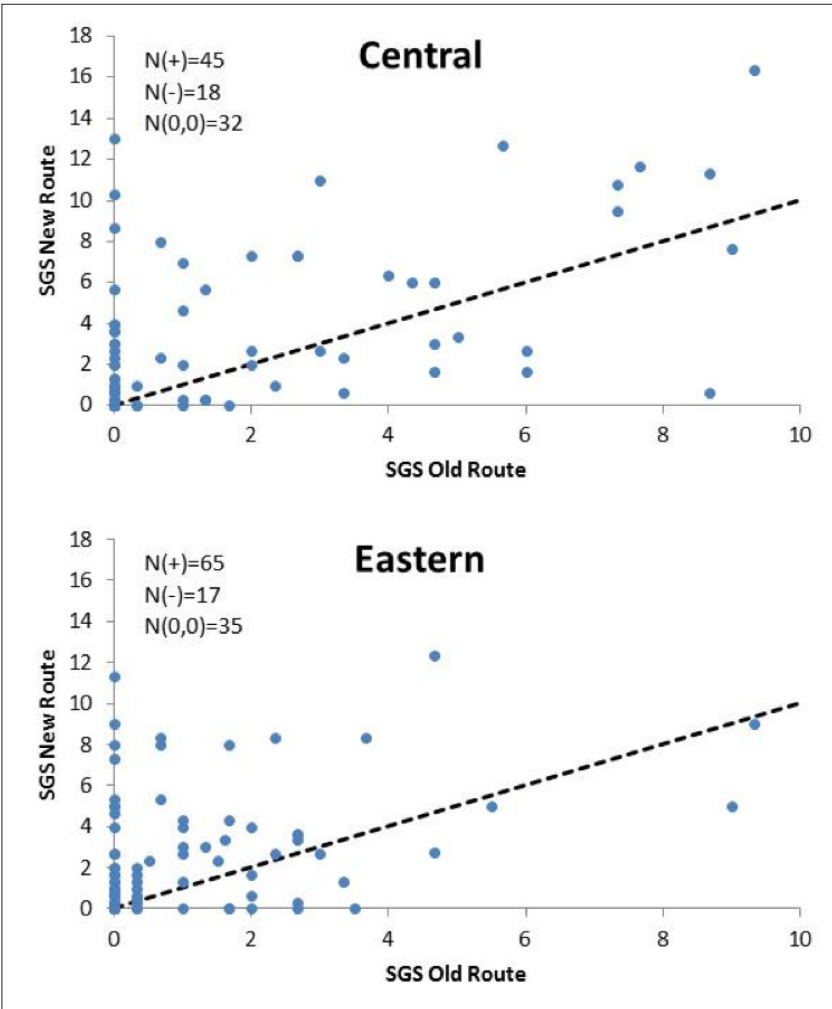

Figure 3. Comparison of discontinued SingingGround Survey (SGS) routes with their replacement routes in the Eastern (A) and Central Management Regions (B). Values based on 3-year average of total woodcock heard during the SGS prior to discontinuance (old route) or after replacement (new route). The dashed line indicates where SGS values for paired old and new routes are the same. In 90 cases of route replacement in the Eastern Management Region, SGS values were: greater at 51 new routes, greater at 23 old routes, and zero at 16 old and new routes. In 84 cases of route replacement in the Central Management Region SGS values were: greater at 36 new routes, greater at 18 old routes, and zero at 30 old and new routes.

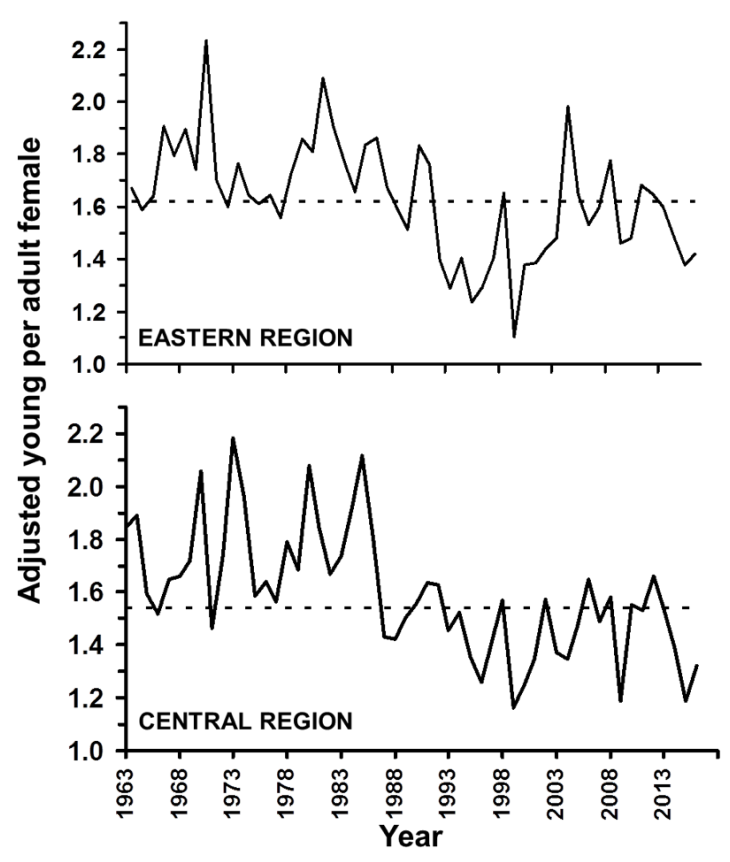

Figure 4. Annual indices of American woodcock recruitment (U.S. only) based on age ratios from wing collection surveys conducted in the United States, 1963-2016. The dashed line is the 1963-2015 average.

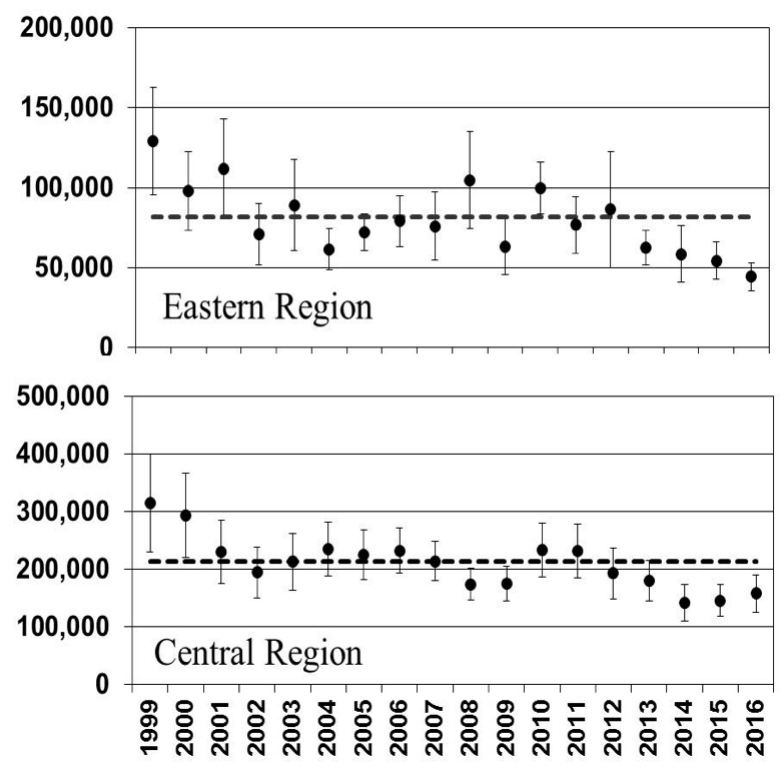

Figure 5. Harvest Information Program Survey estimates of American woodcock harvest in the United States from 1999-2016. The dashed line represents the 1999-2015 average and the error bars represent the $95 \%$ confidence interval of the point estimate. 
SGS index long-term trend clearly indicates a significant decline in singing males during the survey period for both management regions, with the magnitude of the decline being much greater in the Eastern Management Region. We also estimated significant negative trends over the most recent 10-year period in the Eastern but not the Central Management Region, suggesting that the Central Management Region is making progress in meeting the objectives of the Conservation Plan.

Days afield hunting woodcock and total harvest were variable annually but with no clear temporal pattern in each management region from 2002-2013; subsequent to 2013, both measures exhibited a decline in both management regions. The cause of these declines is unknown but could be related to availability of woodcock (as suggested by negative trend in SGS), decrease in access to hunting areas by hunters, fewer people interested in hunting woodcock, or something else.

The magnitude of harvest relative to the woodcock population size cannot be estimated using SGS results; rather, an estimate of absolute population size is needed. Very few estimates of population size exist for American woodcock. Andres et al. (2012) placed the population size at 3-4 million birds in 2006, which would suggest an annual harvest rate of $\sim 7-10 \%$ during that year. Harvest estimates from the early and mid1980 s peaked at about 800,000 to 900,000 birds per year (Straw et al. 1994). Using SGS results to account for the decline in the 2 populations, and assuming there were $3-4$ million birds in 2006, suggests annual harvest rates in the 1980 os were $15-20 \%$. Using a population reconstruction approach (Broms et al. 2010), West (2016) placed the population size between 5.2 and 6.1 million from 1999-2007, and estimated 2013 harvest rates of $0.148(\mathrm{SE}=0.017)$ for adult female woodcock and $0.082(\mathrm{SE}=0.008)$ for other age-sex groups. Using West's (2016) estimate of abundance for 2006 and the estimated trends in SGS to back-calculate abundance produces estimates of annual harvest rates in the range of $11-15 \%$ during the 1980 .

Since 2012, annual harvest has been low relative to long-term averages in both the Eastern and Central Management Regions, and estimated harvest in 2017 in the Eastern Management Region was the lowest since HIP was initiated in 1999 (Seamans and Rau 2017). This may indicate that harvest rate has declined, or that harvest
Table 2. Number of American woodcock wings received from hunters, and indices of recruitment in the United States, 1963-2016. Recruitment indices for individual states with $\geq 125$ submitted wings were calculated as the ratio of immatures per adult female.

\begin{tabular}{|c|c|c|c|c|}
\hline \multirow{2}{*}{$\begin{array}{l}\text { State or } \\
\text { region } \\
\text { of harvest }\end{array}$} & \multicolumn{3}{|c|}{ Wings received } & \multirow[b]{2}{*}{$\begin{array}{r}\text { Recruitment } \\
\text { index }\end{array}$} \\
\hline & Total & $\begin{array}{r}\text { Adult } \\
\text { females }\end{array}$ & Immatures & \\
\hline \multicolumn{5}{|c|}{ EASTERN MANAGEMENT REGION } \\
\hline $\mathrm{CT}$ & 15,462 & 3,464 & 9,411 & 2.7 \\
\hline $\mathrm{DE}$ & 527 & 83 & 360 & $4 \cdot 3$ \\
\hline FL & 678 & 153 & 422 & 2.8 \\
\hline GA & 3,357 & 1,055 & 1,425 & 1.4 \\
\hline ME & 90,514 & 26,774 & 45,168 & 1.7 \\
\hline $\mathrm{MD}$ & 5,004 & 1,221 & 2,840 & 2.3 \\
\hline MA & 25,613 & 8,011 & 12,370 & 1.5 \\
\hline $\mathrm{NH}$ & 38,079 & 12,394 & 17,626 & 1.4 \\
\hline NJ & 27,571 & 6,374 & 16,293 & 2.6 \\
\hline NY & 65,391 & 22,149 & 29,509 & 1.3 \\
\hline $\mathrm{NC}$ & 4,457 & 1,421 & 2,121 & 1.5 \\
\hline PA & 34,120 & 10,832 & 15,714 & 1.5 \\
\hline RI & 2,477 & 479 & 1,639 & 3.4 \\
\hline SC & 3,995 & 1,276 & 1,801 & 1.4 \\
\hline VT & 29,435 & 9,679 & 13,389 & 1.4 \\
\hline VA & 6,277 & 1,654 & 3,379 & 2.0 \\
\hline WV & 6,572 & 1,988 & 3,286 & 1.7 \\
\hline Region Total & 359,529 & 109,007 & 176,753 & 1.62 \\
\hline
\end{tabular}

\begin{tabular}{lrrrl}
\hline CENTRAL MANAGEMENT REGION & & \\
AL & 1,014 & 282 & 462 & 1.6 \\
AR & 563 & 184 & 232 & 1.3 \\
IL & 1,516 & 355 & 854 & 2.4 \\
IN & 8,814 & 2,271 & 4,906 & 2.2 \\
IA & 1,405 & 455 & 622 & 1.4 \\
KS & 50 & 9 & 26 & ---- \\
KY & 1,224 & 336 & 632 & 2.0 \\
LA & 34,064 & 7,654 & 21,994 & 2.9 \\
MI & 147,952 & 48,609 & 71,833 & 1.5 \\
MN & 46,411 & 16,536 & 19,923 & 1.2 \\
MS & 2,016 & 573 & 1,012 & 1.8 \\
MO & 4,672 & 1,307 & 2,286 & 1.8 \\
NE & 13 & 5 & 6 & ---- \\
ND & 4 & 3 & 1 & ---- \\
OH & 15,535 & 4,800 & 7,266 & 1.5 \\
OK & 174 & 38 & 92 & 2.4 \\
TN & 1,367 & 370 & 700 & 1.9 \\
TX & 1,071 & 304 & 533 & 1.8 \\
WI & 98,174 & 33,416 & 45,945 & 1.4 \\
Region Total & $\mathbf{3 6 6 , 0 3 9}$ & $\mathbf{1 1 7 , 5 0 7}$ & $\mathbf{1 7 9 , 3 2 5}$ & $\mathbf{1 . 5 3}$ \\
\hline
\end{tabular}


rate has remained steady while the population has declined. How large an effect harvest might have on the woodcock population is unclear. In general, it is thought that habitat conditions and not harvest caused the long-term decline in the woodcock population (Kelley et al. 2008, McAuley et al. 2005). McAuley et al. (2005) estimated that woodcock fall survival rates were similar between hunted and non-hunted areas. However, Bruggink et al. (2013) estimated that fall survival rates in the western Great Lakes region were significantly lower in hunted areas versus lightly hunted or nonhunted areas. Undoubtedly hunting pressure varies across the range of woodcock, and the effect of hunting on woodcock populations varies at different spatiotemporal scales (e.g., woodcock survival opening week in a small woodlot on publically accessible land versus annually within the western Great Lakes region). The data we present is valid for inference only at large spatial and temporal scales. The continuous decline of woodcock for the past 50 years, especially in the Eastern Management Region, warrants concern about the effect of hunting. However, since HIP was created, annual harvest has varied little and appears uncorrelated with this decline.

SGS routes that were discontinued during the survey period appear to have been replaced by routes that had more woodcock. It may be that woodcock density was similar between old and new routes, but detection probability was greater on the new routes versus the old due
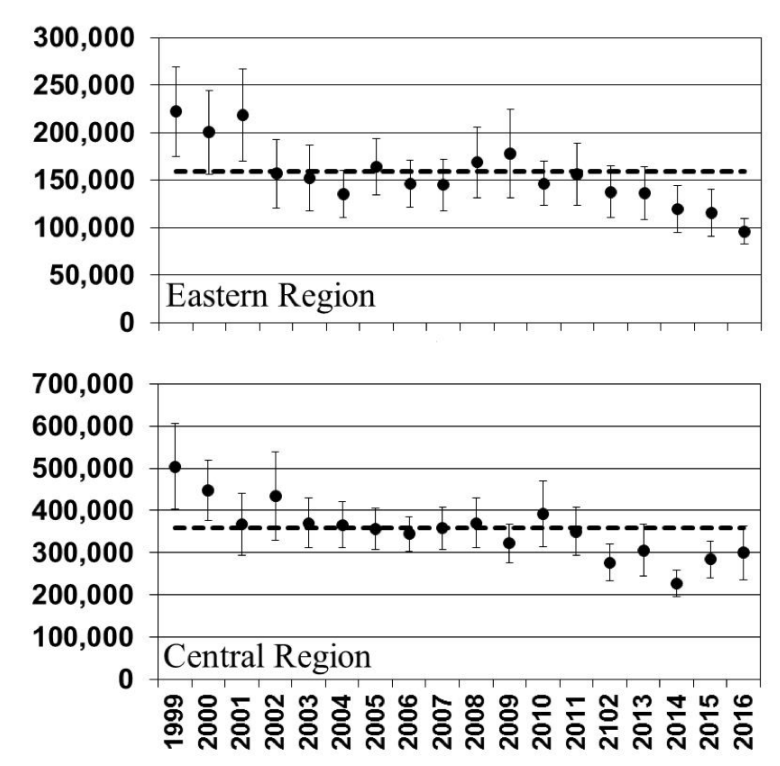

Figure 6. Harvest Information Program Survey estimates of days spent afield by American woodcock hunters in the United States form 1999-2016. The dashed line represents the 1999-2015 average and error bars represent the $95 \%$ confidence interval of the point estimate to roadside noise, as noise was a principle cause of route discontinuation. If the increase in SGS indices was not the result of increased detection probability but rather of better woodcock habitat and thus more woodcock, this would also have introduced bias into the SGS trend estimates, and estimated trends in SGS should indicate steeper declines than they do. On average, SGS indices at new routes increased by 1.1 and 1.2 singing male woodcock over old routes in the Eastern and Central Management Regions, respectively. Assuming routes were replaced uniformly among years, this suggested a small $(\sim 4 \%)$ positive bias in annual SGS estimates.

\section{Management Implications}

Loss of suitable habitat is generally credited as the cause of woodcock population decline (Straw et al. 1994, Kelley et al. 2008). Although the American Woodcock Conservation Plan (Kelley et al. 2008) suggested this loss is most problematic during the breeding season, this has not been tested in comparison to importance of non-breeding (e.g., migration, wintering) habitat. Our results indicate that the woodcock population in the Eastern Management Region appeared to be in a more severe decline than in the Central Management Region. In addition, even with decreasing annual harvest in the Eastern Management Region, the continued population decline indicates that improved habitat management is critically needed. Thus, we recommend that the priority for research is examining how habitat on the breeding, migratory, and wintering grounds affects woodcock in the Eastern Management Region. It is also clear that a better estimate of woodcock population size and the demographic response to harvest are needed to improve harvest management because of uncertainty in the SGS results and what they represent relative to population size and magnitude of harvest.

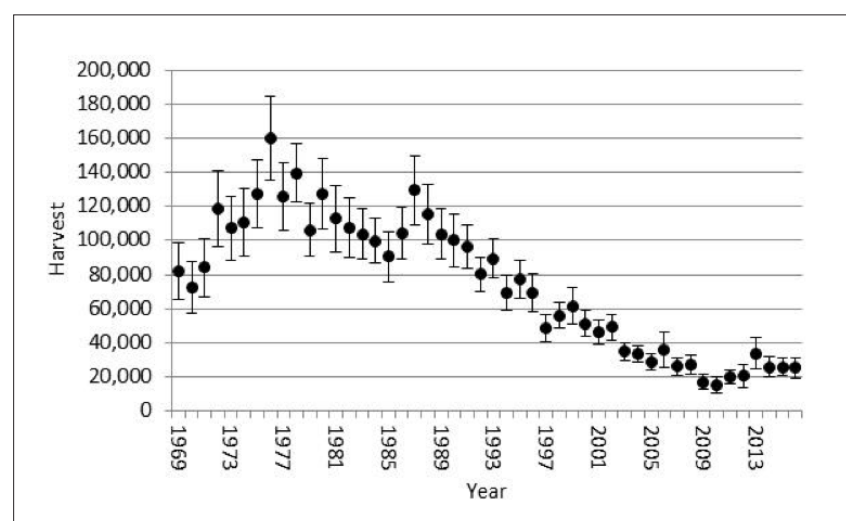

Figure 7. Estimated American woodcock harvest in Canada and associated 95\% confidence intervals, 1969-2016. 


\section{Acknowledgments}

Personnel from the FWS, Canadian Wildlife Service, U. S. Geological Survey (USGS), U.S. Forest Service, Bird Studies Canada, and many state and provincial agencies and other individuals assisted with collecting SGS data and processing wings at the woodcock wingbee. We especially thank all who helped coordinate the SGS, the observers who conducted SGS routes, and the woodcock hunters who sent in wings for the survey. The Branch of Monitoring and Data Management within the Division of Migratory Bird Management (FWS) mailed WCS materials, organized wing submissions, assisted with data management, and provided HIP estimates (special thanks to T. Bethea, T. Ceaser II, S. Chandler, S. Finucane, K. Fleming, P. Garrettson, L. Heckstall, N. Hengst, P. Mathias, P. Padding, R. Raftovich and K. Wilkins). T. Nguyen (FWS) assisted in general maintenance for the SGS data entry website and wingbee application. R. J. Sauer (USGS) developed computer programs for calculating trends and indices from SGS data and conducted this year's analyses for the survey. We thank E. J. Blomberg and two anonymous reviewers for helpful comments.

\section{Literature Cited}

Andres, B.A., P.A. Smith, R.I.G. Morrison, C.L. Gratto-Trevor, S.C. Brown, and C.A. Frils. 2012. Population estimates of North American shorebirds, 2012. Wader Study Group Bull. 119:178-194.

Broms, K., J.R. Skalski, J.J. Millspaugh, C.A. Hagen, and J.H. Schultz. 2010. Using statistical population reconstruction to estimate demographic trends in small game. Journal Wildlife Management 74:310-317.

Bruggink, J.G., E.J. Oppelt, K.E. Doherty, D.E. Andersen, J. Meunier, and R.S. Lutz. 2013. Fall survival of American woodcock in the western Great Lakes region. Journal of Wildlife Management 77:1021-1030.

Case, D.J., and Associates (editor). 2010. Priority information needs for American woodcock: a funding strategy. Developed for the Association of Fish and Wildlife Agencies by the Migratory Shore and Upland Game Bird Support Task Force. 16pp.

Duke, G.E. 1966. Reliability of censuses of singing male woodcock. Journal of Wildlife Management 30:697-707.

Dwyer, T.J., G.F. Sepik, E.L. Derleth, and D.G. McAuley. 1988. Demographic characteristics of a Maine woodcock population and effects of habitat management. U.S. Fish and Wildlife Service, Fish and Wildlife Research 4. 29pp.

Elden, R.C., W.V. Bevill, P.I. Padding, J.E. Frampton, and D.L. Shroufe. 2002. Pages 7-16 in J.M. Ver Steeg and R.C. Elden, compilers. Harvest Information Program: evaluation and recommendations. International Association of Fish and Wildlife Agencies, Migratory Shore and Upland Game Bird Working Group, Ad Hoc Committee on HIP, Washington, D.C., USA.

Gendron, M.H.., and A.C. Smith. 2017. National Harvest Survey web site. Bird Monitoring, National Wildlife Research Centre, Canadian Wildlife Service, Ottawa, Ontario, Canada. http://www. ec.gc.ca/reom-mbs/enp-nhs/index.cfm?do=def\&lang=e

Goudy, W.H. 1960. Factors affecting woodcock spring population indexes in southern Michigan. Thesis. Michigan State University, East Lansing, Michigan, USA.

Kelley, Jr., J.R., S. Williamson and T.R. Cooper. 2008. American Woodcock Conservation Plan: summary of and recommenda- tions for woodcock conservation in North America. Washington: U.S. Fish and Wildlife Publications.

Link, W.A., and J.R. Sauer. 2002. A hierarchical model of population change with application to cerulean warblers. Ecology 83:2832-2840.

Martin, F.W. 1964. Woodcock age and sex determination from wings. Journal of Wildlife Management 28:287-293.

McAuley, D.G., D.M. Keppie and R.M. Whiting Jr. 2013. American woodcock (Scolopax minor), version 2.o. In The Birds of North America (P.G. Rodewald, editor). Cornell Lab of Ornithology, Ithaca, New York, USA.

McAuley, D.G., J.R. Longcore, D.A. Clugston, R.B. Allen, A. Weik, S. Williamson, J. Dunn, B. Palmer, K. Evans, W. Staats, G.F. Sepik and W. Halteman. 2005. Effects of hunting on survival of American woodcock in the Northeast. Journal of Wildlife Management 69:1565-1577.

Mendall, H.L., and C.M. Aldous. 1943. The ecology and management of the American woodcock. Maine Cooperative Wildlife Research Unit, University of Maine, Orono, Maine, USA.

Moore, J.D., T.R. Cooper, R. Rau, D.E. Andersen, J.P. Duguay, C.A. Stewart, and D.G. Krementz. 2019. Assessment of the American woodcock singing-ground survey zone timing and coverage. Pages 181-192 in D.G. Krementz, D.E. Andersen, and T.R. Cooper, Editors. Proceedings of the Eleventh American Woodcock Symposium. University of Minnesota Libraries Publishing, Minneapolis, Minnesota, USA.

Raftovich, R.V., S.C. Chandler, and K.K. Fleming. 2017. Migratory bird hunting activity and harvest during the 2015-16 and 2016-17 hunting seasons. U.S. Fish and Wildlife Service, Laurel, Maryland, USA.

Roy, C., M. Gendron, S.W. Meyer, J.B. Pollard, J. Rodrigue, and J.R. Zimmerling. 2019. Retrospective analysis of American woodcock population and harvest trends in Canada. Pages 228-239 in D.G. Krementz, D.E. Andersen, and T.R. Cooper, Editors. Proceedings of the Eleventh American Woodcock Symposium. University of Minnesota Libraries Publishing, Minneapolis, Minnesota, USA.

Sauer, J.R., and J.B. Bortner. 1991. Population trends from the American Woodcock Sing-Ground Survey, 1970-1988. Journal of Wildlife Management 55:300-312.

Sauer, J.R., W.A. Link, W.L. Kendall, J.R. Kelley, and D.K. Niven. 2008. A hierarchical model for estimating change in American woodcock populations. Journal of Wildlife Management 72:204-214.

Seamans, M.E., and R. Rau. 2017. American woodcock population status, 2017. U.S. Fish and Wildlife Service, unpublished report, Laurel, Maryland, USA.

Sepik, G.F. 1994. A woodcock in the hand. Ruffed Grouse Society, Coraopolis, Pennsylvania, USA.

Straw, J.A., Jr., D.G. Krementz, M.W. Olinde, and G.F. Sepik. 1994. American woodcock. Pages 97-114 in T.C. Tacha and C.E. Braun (eds.) Migratory shore and upland game bird management in North America. Allen Press, Lawrence, Kansas, USA.

U.S. Fish and Wildlife Service. 1990. American woodcock management plan. U.S. Fish and Wildlife Service. Washington, D.C., USA.

West, B.H. 2016. Estimating population trends in American woodcock (Scolopax minor) using population reconstruction models. Thesis, University of Maryland, College Park, Maryland, USA.

Whitcomb, D.A. 1974. Characteristics of an insular woodcock population. Michigan Department of Natural Resources, Wildlife Division Report 2720. Lansing, Michigan, USA.

Woodcock Harvest Strategy Working Group. 2010. Interim American woodcock harvest strategy. Proposal to: Atlantic Flyway Council, Mississippi Flyway Council, Central Flyway Council, and U.S. Fish and Wildlife Service. 